\title{
Production and partial characterization of a crude cold-active cellulase (CMCase) from Bacillus mycoides AR20-61 isolated from an Alpine forest site
}

Elisa Steiner and Rosa Margesin *i)

\begin{abstract}
Purpose: To evaluate the production of a cold-active CMCase (endoglucanase) by Bacillus mycoides AR20-61 isolated from Alpine forest soil and to characterize the crude enzyme.

Methods: After studying the effect of cultivation parameters (medium composition, temperature, $\mathrm{NaCl}$ concentration, $\mathrm{pH}$ ) on bacterial growth and enzyme production, the crude enzyme was characterized with regard to the effect of $\mathrm{pH}$, temperature, and inhibitors on enzyme activity and stability.

Result: Optimum growth and enzyme production occurred at $20-25^{\circ} \mathrm{C}, \mathrm{pH} 7$, and $1-1.5 \%(\mathrm{w} / \mathrm{v}) \mathrm{CMC}$. Despite high biomass production over the whole growth temperature range $\left(10-35^{\circ} \mathrm{C}\right)$, enzyme production was low at 10 and $35^{\circ} \mathrm{C}$. CMC concentration had a minor effect on growth, independent of the growth temperature, but a significant effect on CMCase production at temperatures $\geq 20^{\circ} \mathrm{C}$. The crude enzyme was active over a broad temperature range $\left(0-60^{\circ} \mathrm{C}\right)$; the apparent optimum temperature for activity was at $40-50^{\circ} \mathrm{C}$. The cultivation temperature influenced the effect of temperature on enzyme activity and stability. A significantly higher thermosensitivity of the enzyme produced at a cultivation temperature of $10^{\circ} \mathrm{C}$ compared to that produced at $25^{\circ} \mathrm{C}$ was noted at 50 and $65^{\circ} \mathrm{C}$. The enzyme was highly active over a pH range of $4-6$ and showed optimum activity at pH 5. No activity was lost after 60 min of incubation at $30^{\circ} \mathrm{C}$ and $\mathrm{pH} 4-9$. The CMCase was resistant against a number of monovalent and divalent metal ions, metal-chelating agents, and phenol.

Conclusion: The CMCase produced by the studied strain is characterized by high activities in the low temperature range (down to $0^{\circ} \mathrm{C}$ ) and acidic $\mathrm{pH}$ range, high stability over a broad $\mathrm{pH}$ range, and high resistance against a number of effectors. Our results also demonstrate the different, independent roles of temperature in bacterial growth, enzyme production, nutrient requirements during enzyme production, and enzyme characteristics regarding thermosensitivity, which has not yet been described for cellulases.
\end{abstract}

Keywords: Alpine, Bacteria, Bacillus, Endoglucanase, CMC, Biopolymers

* Correspondence: rosa.margesin@uibk.ac.at

Institute of Microbiology, University of Innsbruck, Technikerstrasse 25, 6020 Innsbruck, Austria

(c) The Author(s). 2020 Open Access This article is licensed under a Creative Commons Attribution 4.0 International License, which permits use, sharing, adaptation, distribution and reproduction in any medium or format, as long as you give appropriate credit to the original author(s) and the source, provide a link to the Creative Commons licence, and indicate if changes were made. The images or other third party material in this article are included in the article's Creative Commons licence, unless indicated otherwise in a credit line to the material. If material is not included in the article's Creative Commons licence and your intended use is not permitted by statutory regulation or exceeds the permitted use, you will need to obtain permission directly from the copyright holder. To view a copy of this licence, visit http://creativecommons.org/licenses/by/4.0/. 


\section{Introduction}

Cellulose is the most abundant renewable biopolymer and one of the most important carbon sources on Earth. It is the major structural component of the cell-wall of terrestrial plants and marine algae and is also produced by some bacteria and terrestrial animals (Teeri 1997). The degradation of cellulose and hemicelluloses represents a key step in terrestrial carbon cycling (LópezMondéjar et al. 2016). Beside this crucial ecological role, cellulose transformation is also of great importance in biotechnology. Enzymatic depolymerization is environmentally friendly. Cellulases cleave the $\beta$-1,4-glycosidic bonds in the cellulose chain. They are widely used in the pulp, textile, food, and feed industries and are involved in the production of value-added products, such as bioethanol, and sustainable energy from biomass (Juturu and Wu 2014; Menendez et al. 2015; de Cassia Pereira et al. 2017).

Cellulolytic enzymes are produced by a number of microorganisms (Islam and Roy 2019). Although it is typically assumed that fungi are the major decomposers of complex plant biopolymers (Boer et al. 2005), numerous bacteria have been described in recent years as efficient cellulose degraders (de Cassia Pereira et al. 2017; Banerjee et al. 2020), often more effective than fungi (Ariffin et al. 2006). Bacteria have a number of advantages compared to fungi: higher growth rates allow for the higher recombinant production of enzymes, they express multienzyme complexes with increased function and synergy, and they inhabit a wide variety of environments and are often resistant to extreme conditions (Sadhu and Maiti 2013; Li et al. 2016).

Most studies on cellulolytic bacteria have been focused on mesophilic or thermophilic representatives. The number of studies on cellulose degraders in cold environments is low ( $\mathrm{Li}$ et al. 2016; Lin et al. 2019; Sun et al. 2020). It has been recognized that cold-active enzymes provide a wide biotechnological potential. They are characterized by high catalytic efficiency at low and moderate temperatures and are thermolabile, which is often desirable in industrial processes (Juturu and $\mathrm{Wu}$ 2014; Collins and Margesin 2019).

In an earlier study (Berger et al. 2020), we demonstrated the ability of a high number of bacterial strains isolated from soil from an Alpine coniferous forest site to produce CMCase. Among the 68 tested strains, $\mathrm{Ba}$ cillus mycoides AR20-61 was the best enzyme producer and was therefore selected for further studies on CMCase production and enzyme characterization. It was the aim of this study to evaluate the production of a cold-active CMCase (endoglucanase) by Bacillus mycoides AR20-61 and to characterize the crude enzyme. We studied the effect of temperature on growth, enzyme production, and enzyme characteristics.

\section{Materials and methods}

\section{Strain}

The bacterial strain used in this study was isolated from soil from an Alpine coniferous forest site (46 35' 16.2" $\left.\mathrm{N}, 11^{\circ} 26^{\prime} 4.9^{\prime \prime} \mathrm{E}\right)$ located $7 \mathrm{~km}$ north of Bozen/Bolzano, Italy, below the Rittner Horn at an altitude of 1724$1737 \mathrm{~m}$ above sea level (França et al. 2016) and identified as member of the species Bacillus mycoides (GenBank accession no. ACU01000002; Berger et al. 2020). The strain was stored at $-80^{\circ} \mathrm{C}$ using ROTI@Store cryovials.

\section{Effect of cultivation parameters on growth and CMCase production}

Growth (OD600) and CMCase activity in the cell-free supernatant obtained by centrifugation were monitored at regular intervals until the stationary phase was reached. Experiments were carried out in triplicate.

To determine the effect of the medium composition on growth and enzyme production, the strain was cultured at $25^{\circ} \mathrm{C}$ and $150 \mathrm{rpm}$ in the following four $\mathrm{pH}$ neutral liquid media supplemented with carboxymethyl cellulose (CMC; Fluka 21900; 0.5\% w/v) (compositions indicated per liter): (i) mineral salts medium $\left(\mathrm{Na}_{2} \mathrm{H}\right.$ $\mathrm{PO}_{4} \cdot 2 \mathrm{H}_{2} \mathrm{O} \quad 3.5 \mathrm{~g}, \quad \mathrm{KH}_{2} \mathrm{PO}_{4} \quad 2.0 \mathrm{~g}, \quad\left(\mathrm{NH}_{4}\right)_{2} \mathrm{SO}_{4} \quad 1.0 \mathrm{~g}$, $\mathrm{MgSO}_{4} \cdot 7 \mathrm{H}_{2} \mathrm{O} 0.2 \mathrm{~g}, \mathrm{Ca}\left(\mathrm{NO}_{3}\right)_{2} \cdot 4 \mathrm{H}_{2} \mathrm{O} 0.05 \mathrm{~g}$, yeast extract $0.05 \mathrm{~g}$ ), (ii) R2A (yeast extract $5.0 \mathrm{~g}$, Bacto Tryptone $0.5 \mathrm{~g}$, $\mathrm{K}_{2} \mathrm{HPO}_{4} 0.3 \mathrm{~g}, \mathrm{MgSO}_{4} \cdot 7 \mathrm{H}_{2} \mathrm{O} 0.05 \mathrm{~g}$ ), (iii) NB (Nutrient broth; Merck 05443; $8.0 \mathrm{~g}$ ), and (iv) Standard I (peptone from casein $7.8 \mathrm{~g}$, peptone from meat $7.8 \mathrm{~g}$, yeast extract $3.0 \mathrm{~g}, \mathrm{NaCl} 6.0 \mathrm{~g}$ ).

The effects of various parameters on growth and enzyme production were determined in medium iii (Standard I) at $150 \mathrm{rpm}$. The effect of temperature was determined at temperatures ranging from 0 to $40{ }^{\circ} \mathrm{C}$ $\left(5{ }^{\circ} \mathrm{C}\right.$ intervals). To determine the effect of $\mathrm{NaCl}$, the medium was supplemented with $0 \%, 0.5 \%, 1 \%, 1.5 \%, 2 \%$, $3 \%, 5 \%, 7.5 \%$, and $10 \%(\mathrm{w} / \mathrm{v}) \mathrm{NaCl}$. The effect of $\mathrm{pH}$ was evaluated in medium with the $\mathrm{pH}$ adjusted to values ranging from $\mathrm{pH} 5$ to 9 using $67 \mathrm{mM}$ citrate buffer ( $\mathrm{pH}$ 5-6) or Tris buffer ( $\mathrm{pH} 7-9)$ at $25^{\circ} \mathrm{C}$. To determine the effect of $\mathrm{CMC}$ concentration and temperature, the strain was cultured in its growth temperature range $\left(10-35^{\circ} \mathrm{C}\right.$; $5^{\circ} \mathrm{C}$ intervals) in medium supplemented with $0.5,1.0$, and $1.5 \%(\mathrm{w} / \mathrm{v}) \mathrm{CMC}$.

\section{Enzyme assays}

Enzyme assays were performed in triplicate in bacterial culture supernatants obtained after centrifugation for 5 $\min$ at $12,000 \times g$.

CMCase (endoglucanase) activity was determined by the 3,5-dinitrosalicyclic acid (DNS) colorimetric method as described by Ariffin et al. (2006) and Li et al. (2016). The crude enzyme $(0.5 \mathrm{ml})$ was mixed with $2 \mathrm{ml}$ of substrate solution $(1 \% \mathrm{w} / \mathrm{v}$ CMC dissolved in $50 \mathrm{mM}$ 
sodium citrate buffer ( $\mathrm{pH}$ 4.8)) and incubated for $30 \mathrm{~min}$ at $30{ }^{\circ} \mathrm{C}$ in a water bath. The reaction was stopped by adding $3 \mathrm{ml}$ DNS reagent (Li et al. 2016), followed by heating for $5 \mathrm{~min}$ in a boiling water bath. After $10 \mathrm{~min}$ of cooling, the absorbance at $540 \mathrm{~nm}$ was determined in a spectrophotometer. The concentration of released glucose was determined from a glucose calibration curve prepared in culture medium. Enzyme blanks, reagent blanks, and glucose standard solutions were treated in exactly the same way like samples. CMCase activity was expressed as the amount of glucose equivalents (GLCeq; micrograms glucose) released per milliliter of crude enzyme solution and incubation time.

Filterpaperase (FP; exoglucanase) activity was determined by using the method described by Wood and Bhat (1988) and Ariffin et al. (2006). The crude enzyme $(0.5 \mathrm{ml})$ was mixed with $2 \mathrm{ml}$ of substrate (Whatman no. 1 filter paper strips; $1 \times 3 \mathrm{~cm}$ and $1 \times 6 \mathrm{~cm}$ ) suspended in $50 \mathrm{mM}$ sodium citrate buffer $(\mathrm{pH} 4.8)$ and incubated for $30 \mathrm{~min}$ at $30^{\circ} \mathrm{C}$ in a water bath. Afterwards, the same procedure as described for CMCase activity was applied.

Cellobiase ( $\beta$-glucosidase) activity was determined according to Wood and Bhat (1988) and Ariffin et al. (2006). To detect cell-free or cell-associated activity, cell-free culture supernatant and cell-containing medium $(0.5 \mathrm{ml})$ was mixed with $2 \mathrm{ml}$ of substrate $(0.15 \% \mathrm{w} / \mathrm{v}$ pNPG (p-nitrophenyl- $\beta$-D-glucopyranoside)) dissolved in $50 \mathrm{mM}$ sodium citrate buffer ( $\mathrm{pH} 4.8$ ) and incubated for $30 \mathrm{~min}$ at $30^{\circ} \mathrm{C}$ in a water bath. The reaction was stopped by adding $2 \mathrm{ml}$ of $1 \mathrm{M} \mathrm{Na}_{2} \mathrm{CO}_{3}$. The absorbance at $400 \mathrm{~nm}$ was determined in a spectrophotometer. The concentration of released pNP (p-nitrophenol) was determined from a pNP calibration curve. Enzyme blanks, reagent blanks, and pNP standard solutions were treated in exactly the same way like samples. Cellobiase activity was expressed as the amount of micrograms pNP released per milliliter of crude enzyme solution and incubation time.

\section{CMCase characterization}

Enzyme characterization was performed in triplicate in cell-free supernatants of cultures grown in Standard I medium ( $\mathrm{pH} 7)$ containing $1 \%(\mathrm{w} / \mathrm{v}) \mathrm{CMC}$ at $25^{\circ} \mathrm{C}$. The effect of $\mathrm{pH}$ on enzyme activity was tested by using substrate solutions prepared in $50 \mathrm{mM}$ citrate buffer (pH 3-6) or Tris buffer ( $\mathrm{pH} 7-9$ ). To test the effect of $\mathrm{pH}$ on enzyme stability, enzyme solutions were incubated with citrate buffer ( $\mathrm{pH} 3-6)$ or Tris buffer ( $\mathrm{pH} 7-9$ ) for $60 \mathrm{~min}$ at $30^{\circ} \mathrm{C}$; afterwards, the residual activity was determined. The effect of potential inhibitors and inductors (metals, chelating agents, detergents, phenolic compounds) on enzyme activity was tested by determining the residual activity after incubating the enzymes with each of the tested agents for $60 \mathrm{~min}$ at $30^{\circ} \mathrm{C}$ (Table 1).
Table 1 Effect of mono- and divalent metal ions, metalchelating agents, surfactants, and phenolic compounds on CMCase activity (mean values of three replicates)

\begin{tabular}{|c|c|c|}
\hline Agent & Concentration & $\begin{array}{l}\text { Residual } \\
\text { activity (\%) }\end{array}$ \\
\hline None & & 100 \\
\hline $\mathrm{Mn}^{2+}\left(\mathrm{MnCl}_{2} \cdot 2 \mathrm{H}_{2} \mathrm{O}\right)$ & $10 \mathrm{mM}$ & 36 \\
\hline $\mathrm{Fe}^{3+}\left(\mathrm{FeCl}_{3}\right)$ & $10 \mathrm{mM}$ & 75 \\
\hline $\mathrm{Mg}^{2+}\left(\mathrm{MgCl}_{2} \cdot 6 \mathrm{H}_{2} \mathrm{O}\right)$ & $10 \mathrm{mM}$ & 111 \\
\hline $\mathrm{Pb}^{2+}\left(\mathrm{Pb}\left(\mathrm{NO}_{3}\right)_{2}\right)$ & $10 \mathrm{mM}$ & 56 \\
\hline $\mathrm{Zn}^{2+}\left(\mathrm{ZnSO}_{4} \cdot 7 \mathrm{H}_{2} \mathrm{O}\right)$ & $10 \mathrm{mM}$ & 111 \\
\hline $\mathrm{Cu}^{2+}\left(\mathrm{CuCl}_{2} \cdot 2 \mathrm{H}_{2} \mathrm{O}\right)$ & $10 \mathrm{mM}$ & 110 \\
\hline $\mathrm{Fe}^{2+}\left(\mathrm{FeCl}_{2} \cdot 4 \mathrm{H}_{2} \mathrm{O}\right)$ & $10 \mathrm{mM}$ & 11 \\
\hline $\mathrm{K}^{+}(\mathrm{KCl})$ & $100 \mathrm{mM}$ & 101 \\
\hline $\mathrm{Na}^{+}(\mathrm{NaCl})$ & $100 \mathrm{mM}$ & 111 \\
\hline EDTA (Titriplex III) & $3 \%(w / v)$ & 109 \\
\hline Ethylene glycol & $3 \%(v / v)$ & 103 \\
\hline Triton $X-100$ & $3 \%(v / v)$ & 125 \\
\hline Tween 20 & $3 \%(v / v)$ & 82 \\
\hline Phenol & $10 \mathrm{mM}$ & 103 \\
\hline
\end{tabular}

To determine whether the cultivation temperature has an influence on the effect of temperature on activity and stability of the enzyme, the strain was cultured at 10 and $25^{\circ} \mathrm{C}$. For the evaluation of the optimum temperature for enzyme activity, the reaction was carried out at various temperatures $\left(0-70^{\circ} \mathrm{C}\right)$ using the CMCase standard assay. For the determination of the effect of temperature on enzyme stability, the crude enzymes were incubated for 10,30 , and $60 \mathrm{~min}$ at $20,35,50$, and $65^{\circ} \mathrm{C}$. After cooling on ice, the residual activity was measured.

\section{Results}

\section{Growth and CMCase production}

The medium composition had a significant effect on growth and CMCase production of the strain investigated in this study. Best growth was obtained in Standard I medium (OD600 14.1), the nutrient-richest among the tested media; about half of this biomass was detected in NB medium (OD600 7.5). Low growth was observed in R2A medium (OD600 1.2) and no growth occurred in the mineral salts medium. The same trend was visible for CMCase production, which was negligible in R2A medium and about twice as high in Standard I medium compared to NB. CMCase production was highest in the early stationary growth phase. $\mathrm{NaCl}$ had almost no growth-inhibiting effect in the range of $0-3 \%(w / v)$. $\mathrm{NaCl}$ contents of $5 \%(\mathrm{w} / \mathrm{v})$ and higher inhibited growth completely (data not shown).

Temperature influenced growth and CMCase production significantly (Fig. 1). The strain showed best growth 


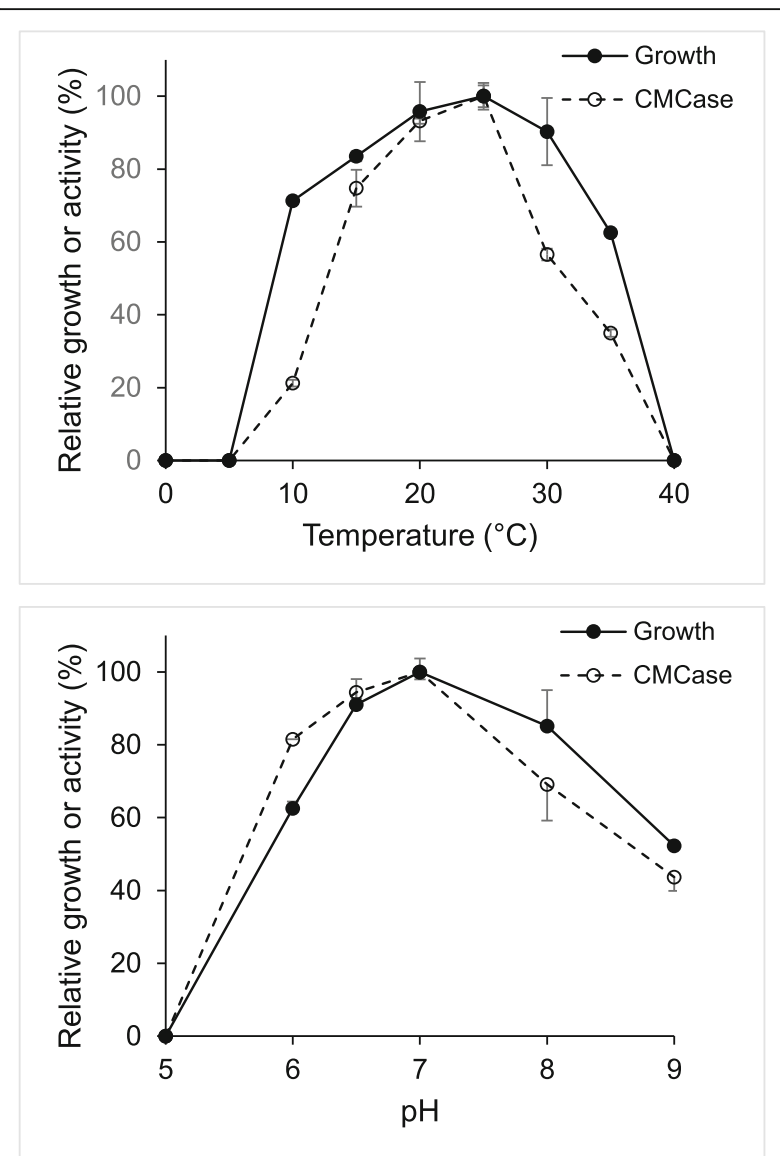

Fig. 1 Effect of temperature (upper panel) and pH (lower panel) on growth (black circles indicate continuous line) and CMCase production (white circle indicates dashed line) by Bacillus mycoides AR20-61 (mean values \pm SD of three replicates)

at $20-25{ }^{\circ} \mathrm{C}$. Ninety percent and $71 \%$, respectively, of the maximum biomass were found at 30 and $10^{\circ} \mathrm{C}$. No growth occurred at $0-5^{\circ} \mathrm{C}$ and at $40^{\circ} \mathrm{C}$. Despite high biomass production at temperatures of $10-35^{\circ} \mathrm{C}$, enzyme production had a narrow temperature optimum of $20-25^{\circ} \mathrm{C}$, coinciding with the optimum temperature for growth, was low at 10 and $35{ }^{\circ} \mathrm{C}(21 \%$ and $35 \%$ of the maximum production, respectively) and reduced by $43 \%$ at $30^{\circ} \mathrm{C}$. At $15{ }^{\circ} \mathrm{C}, 75 \%$ of the enzyme production occurring at $20-25 \%$ were measured.

The optimum $\mathrm{pH}$ for growth and CMCase production (Fig. 1) was pH 7. More than $90 \%$ of the maximum growth and enzyme production were found at $\mathrm{pH} 6.5$; good growth and enzyme production were detected at $\mathrm{pH} 6$ and $\mathrm{pH}$ 8. A pH of 9 resulted in about half of the maximum values. No growth occurred at $\mathrm{pH} 5$.

CMC concentration (5-15 g/l) had a minor effect on growth, independent of the growth temperature, but a significant effect on CMCase production at temperatures of $20^{\circ} \mathrm{C}$ and above (Fig. 2). The maximum CMCase production was obtained at cultivation temperatures of 20



$25^{\circ} \mathrm{C}$ and a CMC concentration of $1-1.5 \%(\mathrm{w} / \mathrm{v})$; lower amounts of CMC resulted in significantly lower enzyme production.

\section{FPase and cellobiase production}

Filter paper consists of crystalline cellulose and is thus suitable to test exoglucanase activity; $50 \mathrm{mg}$ filter paper can release maximally $2 \mathrm{mg}$ of glucose (Wood and Bhat 1988). In our study, this activity was below the detection limit.

Cellobiases ( $\beta$-glucosidases) complete the hydrolysis of cellobiose, released by endo- and exoglucanases, to glucose. Microbial extracellular cellulases can be cell-free or cell-associated (Sadu and Maiti 2013). In our study, cellobiase activity was neither detectable in the cell-free culture supernatant nor in the cell-containing medium.

\section{CMCase characterization}

The crude enzyme was active over a broad temperature range, and remarkably high activities were detectable in the low temperature range (Fig. 3). The apparent 

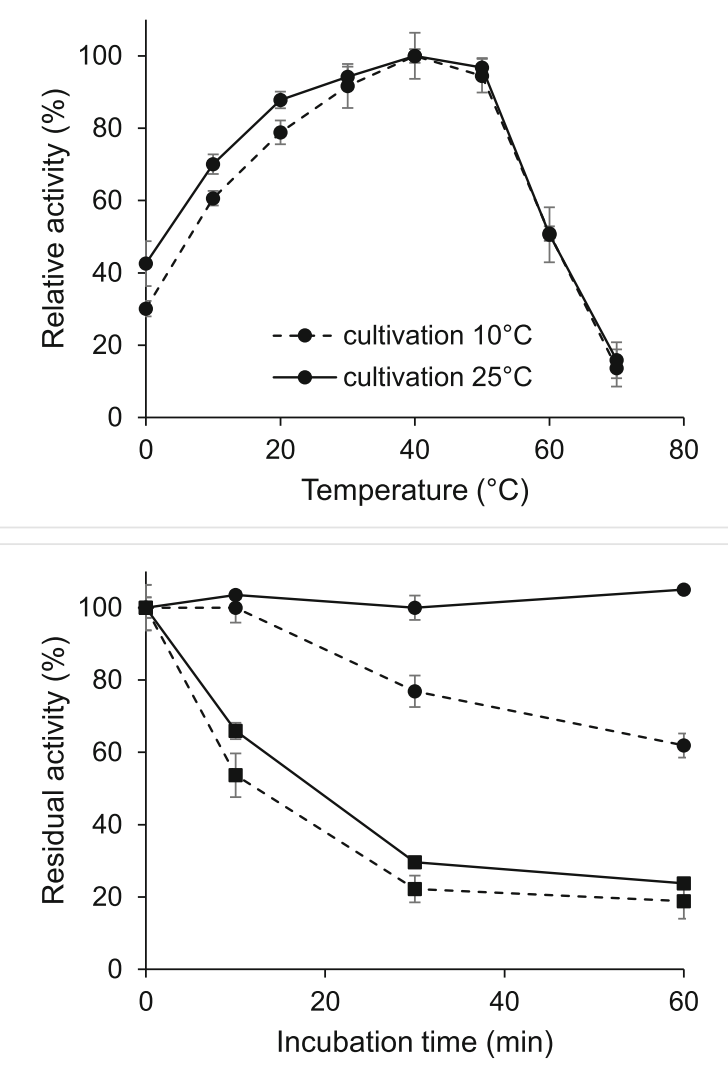

Fig. 3 Effect of temperature on activity (upper panel) and stability (lower panel; black circles indicate $50^{\circ} \mathrm{C}$; black squares indicate $65^{\circ} \mathrm{C}$ ) of the CMCase produced by Bacillus mycoides AR20-61 at cultivation temperatures of $10^{\circ} \mathrm{C}$ (dashed line) and $25^{\circ} \mathrm{C}$ (continuous line) (mean values \pm SD of three replicates)

optimum temperature for CMCase activity was at 40$50{ }^{\circ} \mathrm{C}$, independently of the cultivation temperature $\left(10^{\circ} \mathrm{C}\right.$ and $\left.25^{\circ} \mathrm{C}\right)$. CMCase produced at $10^{\circ} \mathrm{C}$ was more temperature sensitive at temperatures below the optimum temperature for activity than CMCase produced at $25^{\circ} \mathrm{C}$.

Thermostability decreased with increasing temperature. CMCase activity was fully retained after an incubation time up to $60 \mathrm{~min}$ at 20 and $35^{\circ} \mathrm{C}$, independently of the cultivation temperature. However, a higher thermosensitivity of the enzyme produced at $10^{\circ} \mathrm{C}$ compared to that produced at $25^{\circ} \mathrm{C}$ was noted at 50 and $65^{\circ} \mathrm{C}$ (Fig. 3). After $60 \mathrm{~min}$ at $50^{\circ} \mathrm{C}$, the enzyme produced at $25^{\circ} \mathrm{C}$ was not affected, while the enzyme produced at $10^{\circ} \mathrm{C}$ lost $38 \%$ of its activity. An incubation temperature of $65^{\circ} \mathrm{C}$ resulted after $10 \mathrm{~min}$ in a loss of $46 \%$ (cultivation at $10^{\circ} \mathrm{C}$ ) or $34 \%$ (cultivation at $25^{\circ} \mathrm{C}$ ).

The enzyme showed optimum activity at pH 5, 89\% and $74 \%$ of this activity were retained at $\mathrm{pH} 4$ and $\mathrm{pH} 6$, respectively. Almost comparable activities were detected at pH 3 and pH 7 (27-30\%), while at least $80 \%$ of the optimum activity were lost at $\mathrm{pH} 8-9$ and at $\mathrm{pH} 3$ (Fig. 4).

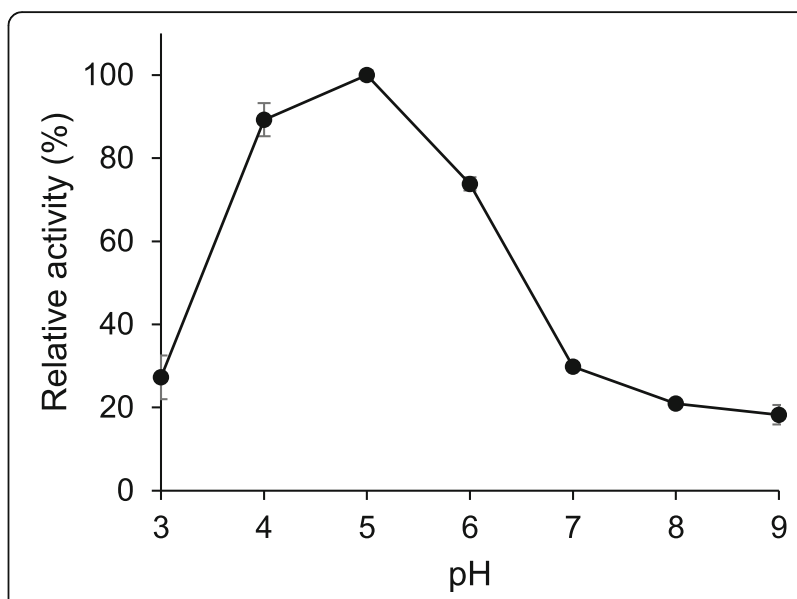

Fig. 4 Effect of $\mathrm{pH}$ on activity of the CMCase produced by Bacillus mycoides AR20-61 (mean values \pm SD of three replicates)

The enzyme lost no activity after 60 min of incubation at $30{ }^{\circ} \mathrm{C}$ and $\mathrm{pH} 4-9$, while about one third of the activity (32\%) was lost at $\mathrm{pH} 3$.

Table 1 shows the effect of various agents on CMCase activity. Several metal ions had an inhibiting effect: $\mathrm{Fe}^{2+}$ $(11 \%$ residual activity $)>\mathrm{Mn}^{2+}>\mathrm{Pb}^{2+}>\mathrm{Fe}^{3+}$. The monovalent ion $\mathrm{K}^{+}$was without any effect, and $\mathrm{Na}^{+}$enhanced activity slightly. Metal chelators had no inhibiting effect, EDTA was slightly stimulating. Detergents had either an inhibitory (Tween 20) or a considerably stimulating (Triton $\mathrm{X}-100$ ) effect. The CMCase was also resistant against phenol

\section{Discussion}

The majority of the organic matter in forest soils originates from plants. Enzyme activities are thus required for the efficient litter decomposition and nutrient turnover in forest soils. The strain investigated in this study, Bacillus mycoides AR20-61, was isolated from a coniferous Alpine forest site. The presence of cellulose degraders at this site has been earlier observed (Margesin et al. 2016; Siles and Margesin 2017). Representatives of the genus Bacillus have been often described as cellulase producers (Shaikh et al. 2013; Behera et al. 2014; Patagundi et al. 2014; Rasul et al. 2015).

The complete microbial hydrolysis of cellulose is obtained by the synergistic process of three major groups of cellulases: endo-1,4- $\beta$-glucanases (CMCase), exo-1,4$\beta$-glucanases (FPase, cellobiohydrolases), and cellobiases ( $\beta$-glucosidases) (Sadhu and Maiti 2013; Juturu and Wu 2014; Yang et al. 2019). Only few bacteria synthesize the complete enzyme system. Bacteria that produce only part of the complete system are called "pseudocellulolytic" and may have obtained the genes encoding these enzymes by horizontal transfer from true cellulolytic bacteria (Sadhu and Maiti 2013). The strain investigated 
in our study belonged to this group and produced only an endoglucanase (CMCase) and was unable to utilize filter paper (crystalline cellulose; this study) and microcrystalline cellulose (data not shown). The same property has been often described for members of the genus Bacillus (Robson and Chambliss 1984; Yan et al. 2011). However, exoglucanase activity (Acharya and Chaudhari 2012; Kim et al. 2012; Ladeira et al. 2015) and membrane-bound cellobiase activity (Kim et al. 2012) also have been detected in Bacillus strains. Most bacteria described as "cellulolytic" in the literature produce only extracellular endoglucanases which cleave the $\beta$-1,4-glycosidic bond only in soluble, artificial derivatives of cellulose, such as $\mathrm{CMC}$, and are thus not able to utilize crystalline cellulose; their cellulases are functional for other purposes such as infection of plant cells (Medie et al. 2012; Koeck et al. 2014). A possible explanation for the occurrence of bacteria that produce only endo- or exoglucanase could be that they use the products resulting from endo- or exocellulolytic activity in their metabolism, instead of using the simple sugars that would result from complete cellulose degradation (Soares et al. 2012).

CMCase activity of Bacillus mycoides AR20-61 was favored in nutrient rich media containing high amounts of CMC, as observed in other studies with bacilli (Karim et al. 2015; Rasul et al. 2015). Interestingly, in our study, the interaction between growth temperature and CMC concentration had a minor effect on growth, but a significant effect on CMCase production. Such a temperature effect has, to the best of our knowledge, not yet been described for cellulases. However, it has been reported for extracellular proteases produced by coldadapted bacteria (Margesin and Schinner 1992) and indicates a substantial difference in cell organization and metabolism at each temperature.

Despite the site-specific cold climate conditions (a mean annual air temperature of $4.0^{\circ} \mathrm{C}$, a mean annual soil temperature of $4.3^{\circ} \mathrm{C}$, a minimum annual soil temperature of $1.9^{\circ} \mathrm{C}$, and a maximum annual soil temperature of $6.1^{\circ} \mathrm{C}$; França et al. 2016), the strain had a growth temperature range of $10-35^{\circ} \mathrm{C}$ and was unable to grow at $0-5{ }^{\circ} \mathrm{C}$ and $40^{\circ} \mathrm{C}$. Thus, it could neither be classified as a psychrophile (due to its inability to grow at $0^{\circ} \mathrm{C}$ ) nor as a mesophile (due to its inability to grow at $40^{\circ} \mathrm{C}$ ). In our study, CMCase activity was even more temperature sensitive than growth. The optimum temperatures for growth and enzyme production were identical $\left(20-25^{\circ} \mathrm{C}\right)$; however, enzyme production at $10^{\circ} \mathrm{C}$ was considerably reduced, in contrast to growth. Nonetheless, the produced enzyme maintained a high level of activity at temperatures down to $0{ }^{\circ} \mathrm{C}$. Remarkably, the cultivation temperature had a significant influence on the sensitivity of the produced enzyme towards temperature. At a cultivation temperature of $10^{\circ} \mathrm{C}$, the enzyme showed a lower relative activity in the temperature range $0-20^{\circ} \mathrm{C}$ compared to the enzyme produced at $25^{\circ} \mathrm{C}$, and a lower thermal stability at $50^{\circ} \mathrm{C}$.

For endoglucanases from bacilli, a broad range of optimum temperatures for activity, ranging from 40 to $70^{\circ} \mathrm{C}$, has been reported (Ariffin et al. 2006; Lin et al. 2012; Sadhu and Maiti 2013; Seo et al. 2013). The optimum temperature for activity of the strain described in our study was at $40-50{ }^{\circ} \mathrm{C}$. Lower optimum temperatures for activity have not been reported for bacilli, but for Actinobacteria $\left(35^{\circ} \mathrm{C}\right.$; Lin et al. 2019) and Gramnegative bacteria $\left(25-35^{\circ} \mathrm{C}\right.$; Sadhu and Maiti 2013; Li et al. 2016).

The isolation source (forest soil) of the strain investigated in this study had a pH of 3.4 (França et al. 2016). The enzyme described in our study showed optimal activity in the acidic $\mathrm{pH}$ range (4-5) and good stability over a broad $\mathrm{pH}$ range (4-9). High stability over a wide pH range (Yan et al. 2011; Gaur and Tiwari 2015) and an acidic $\mathrm{pH}$ optimum for activity has been described for a number of endoglucanases from bacilli (Robson and Chambliss 1984; Lin et al. 2012; Lisdyanti et al. 2012; Lin et al. 2019).

Surprisingly, the CMCase described in this study was resistant against $10 \mathrm{mM}$ phenol. Phenol and phenolic compounds are known to inhibit microbial cellulases (Ximenes et al. 2010; González-Bautista et al. 2017). The CMCase was also resistant against a number of monovalent and divalent metal ions $\left(\mathrm{Mg}^{2+}, \mathrm{Zn}^{2+}, \mathrm{Cu}^{2+}, \mathrm{K}^{+}, \mathrm{Na}^{+}\right)$ and metal-chelating agents. A strong inhibitory effect of $\mathrm{Fe}^{2+}$ on bacterial endoglucanases, such as observed in our study, has been reported (Yin et al. 2010). The effect of divalent ions is not well elucidated and seems to be variable among enzymes produced by various microorganisms. Redox effects on amino acids may decrease or increase enzyme activities (de Cassia Pereira et al. 2017). No general inhibitory or stimulating agents for endoglucanases from bacilli can be recognized from literature (Yin et al. 2010; Yan et al. 2011; Seo et al. 2013; Gaur and Tiwari 2015), which can be attributed to varying concentrations and incubation conditions, beside enzymespecific characteristics.

In conclusion, the results obtained in this study clearly demonstrate the different, independent roles of temperature in growth, enzyme production, nutrient requirements during enzyme production, and enzyme characteristics regarding thermosensitivity. This may be attributed to separate strategies at the cellular level. The temperature range for growth and enzyme production gives no indication about the effect of temperature on activity and stability of the enzyme. Moreover, the latter can be significantly affected by the cultivation temperature, which is of relevance for the selective production of enzymes with desired properties. The CMCase produced by Bacillus mycoides AR20-61 is 
characterized by a number of interesting properties, such as high activities in the low temperature range (down to $0{ }^{\circ} \mathrm{C}$ ) and acidic $\mathrm{pH}$ range, high stability over a broad $\mathrm{pH}$ range and high resistance against a number of effectors (including metal ions and phenol). Such enzymes are of interest for industrial applications (Seo et al. 2013; Juturu and Wu 2014; Menendez et al. 2015).

Clinical trials registration

Not applicable

\section{Authors' contributions}

ES performed and analyzed the experimental research. RM planned the study and wrote the manuscript. The author(s) read and approved the final manuscript.

\section{Funding}

Open access funding provided by University of Innsbruck and Medical University of Innsbruck.

\section{Availability of data and materials}

All data generated and analyzed during this study are included in this article.

\section{Ethics approval and consent to participate}

Not applicable

\section{Consent for publication}

Not applicable

\section{Competing interests}

The authors declare that they have no conflict of interest.

Received: 30 September 2020 Accepted: 4 November 2020 Published online: 25 November 2020

\section{References}

Acharya S, Chaudhary A (2012) Optimization of fermentation conditions for cellulases production by Bacillus licheniformis MVs1 and Bacillus sp. MVS3 isolated from Indian hot spring. Braz Arch Biol Technol 55:497-503

Ariffin H, Abdullah N, Umi Kalsom MS, Shirai Y, Hassan MA (2006) Production and characterization of cellulase by Bacillus pumilus EB3. Int J Eng Technol 3:47-53

Banerjee S, Maiti TK, Roy RN (2020) Production, purification, and characterization of cellulase from Acinetobacter junii GAC 16.2, a novel cellulolytic gut isolate of Gryllotalpa africana, and its effect on cotton fiber and sawdust. Ann Microbiol 70:28

Behera BC, Parida S, Dutta SK, Thatoi HN (2014) Isolation and identification of cellulose degrading bacteria from mangrove soil of Mahanadi River Delta and their cellulase production ability. Am J Microbiol Res 2:41-46

Berger T, Poyntner C, Margesin R (2020) Culturable bacteria from an Alpine coniferous forest site: biodegradation potential or organic polymers and pollutants. Folia Microbiol. https://doi.org/10.1007/s12223-020-00825-1

Boer W, Folmann LB, Summerbell RC, Boddy L (2005) Living in a fungal world: impact of fungi on soil bacterial niche development. FEMS Microbiol Rev 29: 795-811

Collins T, Margesin R (2019) Psychrophilic lifestyles: mechanisms of adaptation and biotechnological tools. Appl Microbiol Biotechnol 103:2857-2871

De Cassia PJ, Giese EC, de Souza Moretti MM, dos Santos Gomes AC, Perrone OM, Boscolo M, da Silva R, Gomes E, Martins DAB (2017) Effect of metal ions, chemical agents and organic compounds on lignocellulolytic enzymes activities. In: Sentürk M (ed) Enzyme inhibitors and activators. IntechOpen, pp 139-164

França L, Sannino C, Turchetti B, Buzzini P, Margesin R (2016) Seasonal and altitudinal changes of culturable bacterial and yeast diversity in Alpine forest soils. Extremophiles 20:855-873

Gaur R, Tiwari S (2015) Isolation, production, purification and characterization of an organic-solvent-thermostable alkalophilic cellulase from Bacillus vallismortis RG-07. BMC Biotechnol 15:19
González-Bautista E, Santana-Morales JC, Ríos-Fránquez FJ, Poggi-Varaldo HM, Ramos-Valdivia AC, Cristiani-Urbina E, Ponce-Noyola T (2017) Phenolic compounds inhibit cellulase and xylanase activities of Cellulomonas flavigena PR-22 during saccharification of sugarcane bagasse. Fuel 196:32-35

Islam F, Roy N (2019) Isolation and characterization of cellulase-producing bacteria from sugar industry waste. Am J BioSci 7:16-24

Juturu V, Wu JC (2014) Microbial cellulases: Engineering, production and applications. Renew Sustain Energy Rev 33:188-203

Karim A, Nawaz MA, Aman A, UI Qader SA (2015) Hyper production of cellulose degrading endo $(1,4) \beta$-d-glucanase from Bacillus licheniformis KIBGE-IB2. J Radiat Res Appl Sci 8:160-165

Kim Y-K, Lee S-C, Cho Y-Y, Oh H-J, Ko YH (2012) Isolation of cellulolytic Bacillus subtilis strains from agricultural environments. ISRN Microbiol 2012:650563

Koeck DE, Pechtl A, Zverlov V, Schwarz WH (2014) Genomics of celluloytic bacteria. Curr Opin Biotechnol 29:171-183

Ladeira SA, Cruz E, Delatorre AB, Barbosa JB, Martins MLL (2015) Cellulase production by thermophilic Bacillus sp. SMIA-2 and its detergent compatibility. Electron J Biotechnol 18:110-115

Li D, Feng L, Liu K, Cheng Y, Hou N, Li C (2016) Optimization of cold-active CMCase production by psychrotrophic Sphingomonas sp. FLX-7 from the cold region of China. Cellulose 23:1335-1347

Lin L, Kan X, Yan H, Wang D (2012) Characterization of extracellular cellulose-degrading enzymes from Bacillus thuringiensis strains. Electron J Biotechnol 15:3

Lin L, Qin N, Guan LY (2019) A novel cold-adapted endoglucanase (M6A) from Microbacterium kitamiense S12 isolated from Qinghai-Tibetan Plateau. Biotechnol Bioprocess Eng 24:544-551

Lisdiyanti P, Suyanto E, Gusmawati NF, Rahayu W (2012) Isolation and characterization of cellulase produced by cellulolytic bacteria from peat soil of Ogan Komering Ilir, South Sumatera. Int J Environ Bioener 3:145-153

López-Mondéjar R, Zühlke D, Becher D, Riedel K, Baldrian P (2016) Cellulose and hemicellulose decomposition by forest soil bacteria proceeds by the action of structurally variable enzymatic systems. Sci Rep 6:25279

Margesin R, Minerbi S, Schinner F (2016) Litter decomposition at two forest sites in the Italian Alps: a field study. Arct Antarct Alp Res 48:127-138

Margesin R, Schinner F (1992) Extracellular protease production by psychrotrophic bacteria from glaciers. Int Biodeterior Biodegrad 29:177-189

Medie FM, Davies GJ, Drancourt M, Henrissat B (2012) Genome analyses highlight the different biological roles of cellulases. Nat Rev Microbiol 10:227-234

Menendez E, Garcia-Fraile P, Rivas R (2015) Biotechnological applications of bacterial cellulases. AIMS Bioeng 2:163-182

Patagundi BI, Shivasharan CT, Kaliwal BB (2014) Isolation and characterization of cellulase producing bacteria from soil. Int J Curr Microbiol Appl Sci 3:59-69

Rasul F, Afroz A, Rashid U, Mehmood S, Sughra K, Zeeshan N (2015) Screening and characterization of cellulase producing bacteria from soil and waste (molasses) of sugar industry. Int J Biosci 6:230-238

Robson LM, Chambliss GH (1984) Characterization of the cellulolytic activity of a Bacillus isolate. Appl Environ Microbiol 47:1039-1046

Sadhu S, Maiti TK (2013) Cellulase production by bacteria: a review. Br Microbio Res J 3:235-258

Seo J, Park TS, Kwon IH, Piao MY, Lee CH, Ha JK (2013) Characterization of cellulolytic and xylanolytic enzymes of Bacillus licheniformis JK7 isolated from the rumen of a native Korean goat. Asian-Australas J Anim Sci 26:50-58

Shaikh NM, Patel AA, Mehta SA, Patel ND (2013) Isolation and screening of cellulolytic bacteria inhabiting different environment and optimization of cellulase production. Univers J Environ Res Technol 3:39-49

Siles JA, Margesin R (2017) Seasonal soil microbial responses are limited to changes in functionality at two Alpine forest sites differing in altitude and vegetation. Nat Sci Rep 7:2204

Soares FL, Melo IS, Dias ACF, Andreote FD (2012) Cellulolytic bacteria from harsh environments. World J Microbiol Biotechnol 28:2195-2203

Sun S, Zhang Y, Liu K, Chen X, Jiang C, Huang M, Zang H, Li C (2020) Insight into biodegradation of cellulose by psychrotrophic bacterium Pseudomonas sp. LKR-1 from the cold region of China: optimization of cold-active cellulase production and the associated degradation pathways. Cellulose 27:315-333

Teeri $\Pi$ (1997) Crystalline cellulose degradation: new insight into the function of cellobiohydrolases. Trends Biotechnol 15:160-167

Wood TM, Bhat KM (1988) Methods for measuring cellulase activities. Meth Enzymol 160:87-112

Ximenes E, Kim Y, Mosier N, Dien B, Ladisch M (2010) Inhibition of cellulases by phenols. Enzyme Microb Tech 46:170-176 
Yan H, Dai Y, Zhang Y, Yan L, Liu D (2011) Purification and characterization of an endo-1,4- $\beta$-glucanase from Bacillus cereus. Afr J Biotechnol 10:16277-16285

Yang S, Yang B, Duan C, Fuller DA, Wang X, Chowdhury SP, Stavik J, Zhang H, Ni

$Y$ (2019) Applications of enzymatic technologies to the production of high-

quality dissolving pulp: a review. Biores Technol 281:440-448

Yin L-J, Lin H-H, Xiao Z-R (2010) Purification and characterization of a cellulase

from Bacillus subtilis YJ1. J Mar Sci Technol 18:466-471

\section{Publisher's Note}

Springer Nature remains neutral with regard to jurisdictional claims in published maps and institutional affiliations.

Ready to submit your research? Choose BMC and benefit from:

- fast, convenient online submission

- thorough peer review by experienced researchers in your field

- rapid publication on acceptance

- support for research data, including large and complex data types

- gold Open Access which fosters wider collaboration and increased citations

- maximum visibility for your research: over $100 \mathrm{M}$ website views per year

At $\mathrm{BMC}$, research is always in progress.

Learn more biomedcentral.com/submissions 